\title{
Red Blood Cell Transfusion Practices in the Neurointensive Care Unit: A Narrative Review
}

Rohini M. Surve ${ }^{1}$ Sonia Bansal ${ }^{1}$ Radhakrishnan Muthuchellappan ${ }^{1}$

\begin{abstract}
Address for correspondence Radhakrishnan Muthuchellappan, DM, Department of Neuroanesthesia and Neurocritical Care, National Institute of Mental Health and Neuro Sciences (NIMHANS), Hosur Road, Bengaluru 560029 Karnataka, India (e-mail: mrks1974@gmail.com).
\end{abstract}

\begin{abstract}
Keywords

- red blood cell transfusion

- neurointensive care unit

- anemia

- acute brain injury

Anemia is common in neurointensive care unit (NICU) patients and is one of the common causes of systemic insults to the brain. Though the recent literature favors restrictive blood transfusion practices over liberal transfusion to correct anemia in the general ICU, whether a similar practice can be adopted in NICU patients is doubtful due to lack of strong evidence. Impairment of cerebral autoregulation and cardiac function following acute brain injury affects the body's compensatory mechanism to anemia and renders the brain susceptible to anemic hypoxia at different hemoglobin $(\mathrm{Hb})$ thresholds. Hence, red blood cell transfusion (RBCT) practice based on a single $\mathrm{Hb}$ threshold value might be inappropriate. On the other hand, allogenic RBCT has its own risks, both in short and in long run, leading to adverse outcomes. Thus, instead of relying only on arbitrary $\mathrm{Hb}$ values, a better way to decide the need for RBCT in $\mathrm{NICU}$ patients is to target parameters based on systemic and regional cerebral oxygenation. This approach will help us to individualize RBCT practices. In this narrative review, based on the available literature, authors have discussed the impact of anemia and blood transfusion on the immediate and late neurological outcomes and the current role of regional brain monitoring in guiding blood transfusion practices. In the end, authors have tried to update on the current RBCT practices in neurosurgical and neuromedical patients admitted to the NICU.
\end{abstract}

\section{Introduction}

Red blood cell transfusion (RBCT) practices in the intensive care unit (ICU) have undergone a paradigm shift from liberal (hemoglobin [Hb] threshold: $10-11 \mathrm{~g} / \mathrm{dL}$ ) to restrictive strategies (Hb threshold: 7-9 g/dL). ${ }^{1-3}$ Systematic reviews have shown decreased or no change in adverse outcomes following a restrictive transfusion strategy ${ }^{4,5}$ However, most literature on RBCT has focused on stable patients in the general ICU. Hence, extrapolating these results to patients admitted to the neuro-ICU (NICU) should be done with caution. Recent literature, mainly observational, has shown adverse outcomes associated with both anemia and RBCT in the NICU patients. ${ }^{6-14}$

\section{Concerns of Anemia in Patients in Neurointensive Care Unit}

The World Health Organization (WHO) defines anemia as an Hb concentration $<11,12$, and $13 \mathrm{~g} / \mathrm{dL}$ in children, women, and men, respectively. ${ }^{15}$ Apart from preexisting anemia, patients during their NICU stay can develop anemia due to multiple factors, such as hemodilution following fluid resuscitation, blood loss (e.g., surgical drain, postoperative hematoma), repeated phlebotomies, associated multiple injuries, coagulopathies, impaired erythropoiesis, and reduced red blood cell (RBC) survival secondary to inflammation and nutritional deficiencies. ${ }^{16,17}$ As the brain does not store its fuel, namely glucose and oxygen, it needs a constant supply of the same received

January 1, 2019

accepted

February 14, 2019

published online

June 4, 2019
Dol https://doi.org/

10.1055/s-0039-1685251

ISSN 2348-0548.
Copyright $\odot 2019$ Indian Society of Neuroanaesthesiology and Critical Care
License terms

() (1) $\ominus \circledast$ 
through circulation of around $15 \%$ of cardiac output. Hence, it is vulnerable to hypoxia in anemic states. As a result of this, there is a general sense of hesitation among intensivists to follow restrictive RBCT in NICU patients. Acute brain injury (ABI) can impair cerebral autoregulation and cardiac function, thereby affecting the body's compensatory mechanism to anemia, which include systemic vasodilation, reduced viscosity, increased cardiac output, and increased oxygen extraction. These mechanisms, if present in ABI patients, can further compromise brain perfusion by increasing intracranial pressure (due to vasodilation and increased cerebral blood volume). This renders the brain susceptible to anemia at different $\mathrm{Hb}$ thresholds. ${ }^{18-20}$ Hence, RBCT practice based on a single $\mathrm{Hb}$ value threshold might culminate into inappropriate RBCT, either inadequate or unwanted RBCT. Further, allogenic RBCT has its risks, both in short and in the long run, which in turn can lead to adverse outcomes. ${ }^{21,22}$

\section{Concerns of Red Blood Cell Transfusion in Patients in Neurointensive Care Unit}

The primary goal of RBCT in NICU patients is to improve the cerebral oxygen delivery $\left(\mathrm{DO}_{2}\right)$, which depends on cerebral blood flow (CBF) and arterial oxygen content $\left(\mathrm{CaO}_{2}\right)$, which include $\mathrm{Hb}$ and oxygen saturation $\left(\mathrm{SaO}_{2}\right)$. Improving $\mathrm{DO}_{2}$ to the brain need not necessarily result in improved $\mathrm{O}_{2}$ utilization (e.g., mitochondrial dysfunction) ${ }^{23}$ Studies in varied neurosurgical population such as patients with traumatic brain injury (TBI) and subarachnoid hemorrhage (SAH) have documented adverse events such as delayed cerebral ischemia (DCI), infection, thrombotic events, allergic reactions, and transfusionrelated lung injury. Further, whether improved oxygenation translates into improved outcomes largely remains unknown. Hence, the indication for RBCT in a given NICU patient cannot be decided solely by the Hb value.

\section{Role of Physiological Triggers in Guiding Red Blood Cell Transfusion}

A better approach to decide the need for RBCT would be to look at the physiological parameters, which provide information on the oxygen delivery and consumption balance. These parameters, called physiological triggers, can be global such as central venous oxygen saturation $\left(\mathrm{ScvO}_{2}\right)$, jugular venous oximetry $\left(\mathrm{SjvO}_{2}\right)$, or regional like near-infrared spectroscopic-based cerebral oximetry $\left(\mathrm{rSO}_{2}\right)$, brain tissue oxygen tension $\left(\mathrm{PbtO}_{2}\right.$ ), and cerebral microdialysis (CMD). In recent years, there is a great interest in utilizing these cerebral oxygenation monitoring modalities to decide the need for RBCT. Studies have shown improvement in cerebral oxygenation and metabolic parameters following RBCT, though not the neurologic outcome. ${ }^{24-27}$

\section{Recent Guidelines on Red Blood Cell Transfusion}

Due to the lack of high-quality evidence, transfusion triggers in NICU patients remains controversial. Thus, in the panorama of the RBCT practices in NICU patients, there is an urgent need to identify threshold cutoffs for $\mathrm{Hb}$ (which is routinely monitored) and other physiological parameters to guide the RBCT practices. Recent guidelines published by various scientific societies recommend the use of restrictive RBCT strategy with $\mathrm{Hb}$ trigger $<7 \mathrm{~g} / \mathrm{dL}$, mostly in hemodynamically stable general ICU patients of all ages. ${ }^{4,5,28-32}$ However, just a few societies have attempted to address the transfusion trigger in the NICU patients and are summarized in - Table $1 \mathbf{1}^{28,30,32}$ Some of these guidelines also recommend considering the clinical status of patients before deciding on RBCT. ${ }^{5,29}$

\section{Intercontinental Disparity in Red Blood Cell Transfusion Practices}

In spite of the existence of published guidelines for determining the need for RBCT, it is not uniformly practiced. There is a considerable variation in transfusion practices between individuals, institutions, and countries. Recently published two international surveys showed wide interICU variation and lack of consensus in RBCT practices. In a survey conducted across the European and Israel ICUs, in TBI patients (CENTER-TBI), only $52 \%$ of the ICUs had a

Table 1 Recommendations on RBC transfusion in patients admitted to NICU

\begin{tabular}{|c|c|}
\hline Neurologic condition/disease & Currently available recommendation \\
\hline TBI & 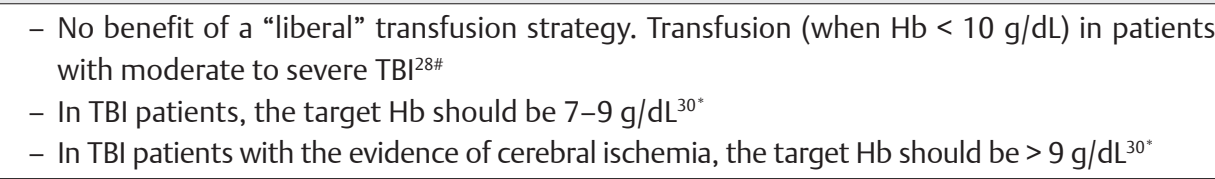 \\
\hline aSAH & - In SAH patients, the target $\mathrm{Hb}$ should be $8-10 \mathrm{~g} / \mathrm{dL}^{30}$ \\
\hline Acute ischemic stroke & - In patients with acute ischemic stroke, the $\mathrm{Hb}$ should be maintained above $9 \mathrm{~g} / \mathrm{dL}^{30^{*}}$ \\
\hline $\begin{array}{l}\text { Pediatric ABI (e.g., severe TBI or } \\
\text { cerebrovascular stroke) }\end{array}$ & $\begin{array}{l}\text { RBC transfusion could be considered if the } \mathrm{Hb} \text { falls between } 7 \text { and } 10 \mathrm{~g} / \mathrm{dL} \text { (expert-based } \\
\text { recommendation). } \text {. }^{22 \mathrm{~s}}\end{array}$ \\
\hline
\end{tabular}

Abbreviations: ABI, acute brain injury; aSAH, aneurysmal subarachnoid hemorrhage; Hb, hemoglobin; NICU, neurointensive care unit; RBC, red blood cell; $\mathrm{SAH}$, subarachnoid hemorrhage; TBI, traumatic brain injury.

Adapted from refs. ${ }^{28,30,32}$ Readers are referred to references 28,30 and 32 for detailed descriptions of the recommendations.

"Society of Critical Care Medicine Recommendations (2009) 28

*Bitish Committee for Standards in Haematology Guidelines (2012) ${ }^{30}$

sPediatric Critical Care Transfusion and Anemia Expertise Initiative (TAXI) (2018) 32 
defined Hb-target for initiating RBCT, of which $41 \%$ transfused at $\mathrm{Hb}$ threshold of 7 to $9 \mathrm{~g} / \mathrm{dL}$ and the remaining $59 \%$ transfused at $\mathrm{Hb}$ threshold of $10 \mathrm{~g} / \mathrm{dL}^{33}$ Another international survey was done in ABI patients (both neurotrauma and nontraumatic neurological conditions), Hb trigger of $7-8 \mathrm{~g} / \mathrm{dL}$ was used to initiate RBCT by $54 \%$ of the ICU clinicians. However, in certain neurological conditions such as TBI, SAH, and ischemic stroke, $57 \%$ of physicians chose a higher Hb-trigger of around $9 \mathrm{~g} / \mathrm{dL}^{34}$

In this narrative review, authors have discussed the effect of anemia and RBCT in specific neurological/neurosurgical disorders and their effects on the neurologic outcome. The authors have tried to update on the current trends and practices of RBCT, current role of regional brain monitoring in guiding the RCBT, and probable transfusion trigger based on the available published literature and guidelines in these disorders. MeSH keywords used to search the databases (Google Scholar, EMBASE, PubMed) include "red blood cell transfusion," "anemia," "neurointensive care unit," and "acute brain injury," "aneurysmal subarachnoid hemorrhage," "stroke," "acute ischemic stroke," "intracerebral hemorrhage," "central venous thrombosis," "elective neurosurgery," "spine surgery," "spine trauma," "pediatric neurosurgery," "myasthenia gravis," "Guillain-Barre syndrome," "neuro-infections," and "neurologic outcome."

\section{Traumatic Brain Injury}

The acute phase of TBI is associated with reduced CBF, in addition to hypotension and/or anemia. All these worsen cerebral oxygen supply thereby compromising neuronal survival has got prognostic implications. ${ }^{935-38}$ Anemia-induced compensatory vasodilation can increase intracranial pressure and further worsen cerebral ischemia. Anemia has been shown to have an inverse linear relation with poor outcome (i.e., low values associated with poor outcomes)..$^{38}$ Baseline $\mathrm{Hb}$ of $<9 \mathrm{~g} / \mathrm{dL}$ predicted worse outcome and increased mortality in TBI patients, but when $\mathrm{Hb}$ was $>10 \mathrm{~g} / \mathrm{dL}$, outcomes were found to be better., ${ }^{9,0,39}$

TBI patients are prone to receive RBCT in the NICU due to blood loss in the surgical drain, blood loss from associated extracranial injuries, and blood loss from acute traumainduced coagulopathy. However, administration of RBCT is not always associated with better outcomes, especially if it is done for the sole purpose of increasing $\mathrm{Hb}$ values (e.g., to target $>10 \mathrm{~g} / \mathrm{dL}$ ). ${ }^{40-44}$ Moreover, RBCT is associated with increased complications, and risk factors identified for increased complications following RBCT in TBI patients included nonanemic/nonbleeding patients during RBCT, younger patients ( $<55$ years), absence of associated comorbidities, and volume of RBCT. ${ }^{14,40,43,45,46}$ Literature on long-term functional outcomes with RBCT in TBI patients is limited and fails to show any improvement following RBCT. ${ }^{45-47}$

Both $\mathrm{Hb}$ and cerebral oxygenation-based targets have been used and studied to decide RBCT in these patients. In studies targeting physiologic parameters, RBCT has shown differential improvement in TBI patients. In a recently published prospective study, the authors proposed $\mathrm{ScvO}_{2}$ as a physiologic trigger to decide $\mathrm{RBCT}$ requirement and identified
$\mathrm{ScvO}_{2}<70 \%$ as the cutoff for deciding RBCT in stable adult patients admitted to NICU. ${ }^{25}$ In another study, RBCT led to a significant improvement in the near-infrared-based regional cerebral oxygenation $\left(\mathrm{rSO}_{2}\right)$ and reductions in the cerebral fractional oxygen extraction (CFOE) in TBI patients, especially when their baseline $\mathrm{rSO}_{2}$ was $\leq 60 \%{ }^{26}$ However, in both these studies, neurologic outcomes were not studied. McCredie et al did not observe improvement in the $\mathrm{rSO}_{2}$ following $\mathrm{RBCT}$ in their cohort of severe TBI patients, which could be due to high baseline $\mathrm{rSO}_{2}(69 \%)$ in their patients. ${ }^{48}$ In a randomized controlled trial conducted on NICU patients, RBCT requirements reduced when RBCT was guided by $\mathrm{rSO}_{2}(<60 \%)$ as against $\mathrm{Hb}$-guided, though the overall outcomes remained the same. ${ }^{27}$ Changes in brain tissue oxygenation $\left(\mathrm{PbtO}_{2}\right)$ were studied following RBCT in TBI patients. ${ }^{23,24}$ It was shown that $\mathrm{Hb}$ levels $<9 \mathrm{~g} / \mathrm{dL}$ were associated with $\mathrm{PbtO}_{2}<20 \mathrm{~mm} \mathrm{Hg}$ and an unfavorable outcome. ${ }^{49}$ Baseline $\mathrm{PbtO}_{2}<15 \mathrm{~mm} \mathrm{Hg}$ predicted maximum increase in brain oxygenation following RBCT. ${ }^{24}$ In a randomized clinical trial comparing two different $\mathrm{Hb}$ thresholds ( $<7$ vs. $10 \mathrm{~g} / \mathrm{dL}$ ) for RBCT, hypoxic episodes $\left(\mathrm{PbtO}_{2}\right.$ $<15 \mathrm{~mm} \mathrm{Hg}$ ) were observed more frequently in patients with low transfusion trigger $(p=0.04) .^{50}$ Administering RBCT based on $\mathrm{Hb}$ values, in spite of a normal $\mathrm{PbtO}_{2}$, results in impaired cerebral autoregulation. ${ }^{51}$ Although CMD seems to be useful for neuroprognostication, there is no literature describing the role of CMD in deciding RBCT in TBI patients. Thus, the clinical utility of CMD-guided RBCT is still unexplored..$^{52,53}$

The existing literature and guidelines suggest that RBCT at $\mathrm{Hb}>10 \mathrm{~g} / \mathrm{dL}$ is not warranted in TBI patients. Acceptable $\mathrm{Hb}$ trigger for RBCT should be between 7 and $9 \mathrm{~g} / \mathrm{dL}$, with due consideration given to the underlying clinical condition, ongoing blood loss, hemodynamic status, associated extracranial injuries, and cerebral oxygenation-based information. ${ }^{28,30}$

\section{Aneurysmal Subarachnoid Hemorrhage}

The principal cause of secondary brain injury following aneurysmal subarachnoid hemorrhage (aSAH) is DCI that is commonly caused by cerebral vasospasm (CVS). In the setting of cerebral ischemia, as the flow cannot be increased through narrow spastic vessels, it seems logical to keep the Hb levels high to increase oxygen delivery and minimize ischemia. Clinical studies have also shown an increased incidence of DCI, cerebral infarction, and poor outcome in anemic SAH pat ients. ${ }^{8,1254-56}$ However, in a multicenter cohort study on SAH patients, RBCs were transfused only when the $\mathrm{Hb}$ fell below $8 \mathrm{~g} / \mathrm{dL}$ (66.3\% of cohorts), and this practice was not associated with poor outcome. ${ }^{13}$ In fact, researchers have shown that administering blood despite $\mathrm{Hb}>10 \mathrm{~g} / \mathrm{dL}$ has led to improved outcomes. ${ }^{55}$ In a multicenter cohort study, most patients received $\mathrm{RBCT}$ when $\mathrm{Hb}$ was $<8 \mathrm{~g} / \mathrm{dL}$ (66.3\%), which was not associated with poor outcome. ${ }^{13}$ The same group is currently doing a multicenter randomized pilot trial comparing two transfusion thresholds for $\mathrm{Hb} 8$ versus $10 \mathrm{~g} / \mathrm{dL}$ in SAH patients (SAHaRA [Aneurysmal SubArachnoid Hemorrhage-Red Blood Cell Transfusion And Outcome] trial) (NCT03309579). On the contrary, there are studies on SAH patients, which have shown poor outcomes and increased thrombotic and infectious complications with RBCT. ${ }^{12,57-60}$ 
Recently, scientists have focused on brain oxygenation and metabolism monitoring to titrate RBCT in SAH patients. They observed brain tissue hypoxia $\left(\mathrm{PbtO}_{2}<15 \mathrm{~mm} \mathrm{Hg}\right.$ ) when $\mathrm{Hb}$ fell below $9 \mathrm{~g} / \mathrm{dL}^{61-63}$ Diringer group showed improved $\mathrm{DO}_{2}$ following RBCT in SAH patients using positron emission tomography (PET) ${ }^{64}$ They could reproduce their results for a wider range of $\mathrm{Hb}(7-13 \mathrm{~g} / \mathrm{dL})$ in patients at risk for DCI. ${ }^{65}$ Other brain-specific monitoring such as cerebral oximetry and cerebral microdialysis has been used to study changes during RBCT in SAH patients. ${ }^{53,66}$

In aSAH patients, the British Committee for Standards in Haematology (BCSH) and Neurocritical Care Society recommend RBCT to target $\mathrm{Hb}>8-10 \mathrm{~g} / \mathrm{dL}^{30,67}$ Existing literature suggests keeping the $\mathrm{Hb}$ concentration $>9 \mathrm{~g} / \mathrm{dL}$ to improve patients' outcome. Until further evidence is generated, restrictive transfusion practices do not seem to be suitable in SAH patients who show evidence of cerebral ischemia.

\section{Stroke}

\section{Ischemic Stroke}

Most of the existing work suggests that both extremes of $\mathrm{Hb}$ concentrations are associated with increased risk of death and disability at short- and long-term follow-up (nonlinear or U-shaped relationship). ${ }^{6,68-70}$ In a recent systematic review and meta-analysis, anemia was found to be associated with an increased risk of mortality in ischemic stroke as well as in patients with hemorrhagic stroke, albeit at a lower magnitude of association (odds ratio [OR]: 1.46, confidence interval [CI]: 95\% 1.23-1.74). ${ }^{70}$ However, the literature also exists refuting anemia as a predictor of poor outcome after stroke. ${ }^{71}$ Recently published two studies did not find an association between both anemia and RBCT with the mortality and 3 months functional outcome, though anemia increased the length of ICU stay and increased the duration of mechanical ventilation. ${ }^{71-74}$ Using a mathematical modeling study, progressive reduction in the oxygen uptake was noted in the ischemic penumbra at $\mathrm{Hb}$ of $<10 \mathrm{~g} / \mathrm{dL} .{ }^{75}$

\section{Intracranial Hemorrhage}

Stroke due to intracranial hemorrhage (ICH) is associated with very high mortality, and the most important factor determining the prognosis is the volume of ICH. Anemia has been found to be an independent predictor of hematoma volume and 30-day mortality. ${ }^{76}$ RBCT seems to improve 30-day survival rate in elderly patients. ${ }^{77}$ However, in patients with Glasgow coma scale (GCS) of 4-8, RBCT failed to improve $\mathrm{PbtO}_{2}$ or reduce lactate-pyruvate ratio. Only when the $\mathrm{Hb}$ was $<7 \mathrm{~g} / \mathrm{dL}$, RBCT increased cerebral perfusion pressure consequent to an increase in mean blood pressure. ${ }^{78}$

\section{Cerebral Venous Thrombosis}

Cerebral venous thrombosis (CVT) manifests commonly as hemorrhagic infarction. It is an uncommon cause of stroke as compared with arterial stroke and occurs in both children and in adults. Common causes include steroid therapy, pregnancy, oral contraceptive use, alcohol consumption, blood dyscrasia, infection, anemia, and dehydration. Anemia is found to be an independent predictor of poor functional outcome in patients with CVT. ${ }^{79,80}$ Currently there are no data published on transfusion practices in CVT patients.

The optimal $\mathrm{Hb}$ for the management of stroke remains unclear. Guidelines recommend maintaining an $\mathrm{Hb}$ concentration $>9 \mathrm{~g} / \mathrm{dL}$ in patients with an acute ischemic stroke. Literature is sparse on ICH and none in CVT to guide RBCT, and hence the above-mentioned threshold can be followed until further evidence is available.

\section{Neurosurgery}

Perioperative anemia in neurosurgical patients, irrespective of its severity, has been found to be associated with increased hospital stay though not mortality and morbidity. ${ }^{81}$ Intraoperative blood loss and volume deficits remain the most common indication necessitating intra- and postoperative RBCT. Infants and pediatric patients require more RBCT when compared with adults, especially in procedures such as craniosynostosis. ${ }^{82-85}$ Among the elective neurosurgical procedures, significant blood loss is seen in meningiomas, cerebellopontine tumors, hemangioblastomas, metastatic tumors, vascular lesions, and spine surgeries. ${ }^{85-87} \mathrm{~A}$ certain class of intracranial tumors such as metastatic lesions are more prone to induce disseminated intravascular coagulation that in turn increases RBCT requirements. ${ }^{88,89}$

Apart from the conventional complications associated with RBCT, there is a concern regarding transfusion-related immunomodulatory effects in neuro-oncology patients. It is speculated that RBCT may promote tumor growth by impairing the body's innate ability to suppress tumor growth and spread..$^{90}$ Allogenic leucocytes and stored RBCs are probably responsible for this immunomodulatory effect. Also, perioperative leukodepleted RBCT is associated with increased recurrence of tumor and decreased survival. ${ }^{22,91}$ For fear of these side effects, many clinicians adopt various strategies to reduce allogenic RBCT in neuro-oncology patients. These include preoperative autologous blood donation (PAD), intraoperative autologous blood transfusion (ABT), preoperative administration of erythropoiesis-stimulating agents (EPO), and use of hemostatic agents such as tranexamic acid. ${ }^{84,92-96}$

\section{Spine Injury and Spine Surgeries}

Patients with traumatic spinal cord injury (SCI) and following complicated spine surgeries frequently require prolonged NICU care and are prone to acute (due to the intraoperative blood loss) as well as chronic anemia, which in turn can affect the outcome. ${ }^{97,98}$ The optimum Hb trigger in the ICU management of traumatic $\mathrm{SCl}$ or other spine surgeries is not known. In a retrospective study, it was noted that spine surgery patients who received RBCT and whose nadir $\mathrm{Hb}$ values were between 8 and $10 \mathrm{~g} / \mathrm{dL}$ had prolonged hospital stay, more surgical site infections, and mortality. ${ }^{99}$ This questions the practice of liberal transfusion strategy extrapolated from brain injury patients, in this subset of patients. On the other hand, one must keep in mind that anemia is an important risk factor for ischemic optic neuropathy, which is one of the common causes of postoperative visual loss in prone spine surgeries. ${ }^{100}$ 


\section{Pediatric Neurocritically III Patients}

There is no direct evidence to guide the transfusion practice in the pediatric NICU patients. Very recently, based on the existing limited literature, the Pediatric Critical Care Transfusion and Anemia Expertise Initiative Consensus Conference recommended consideration of $\mathrm{RBCT}$ for $\mathrm{Hb}$ concentration between 7 and $10 \mathrm{~g} / \mathrm{dL}$ in a critically ill child with $\mathrm{ABI}$ and did not support the use of $\mathrm{PbtO}_{2}$ monitoring to guide RBCT decisions. ${ }^{32}$ Cerebral oximetry is extensively studied in the non-neurocritically ill pediatric patients, and with regard to RBCT, it seems promising. ${ }^{101}$

\section{Miscellaneous Neurologic Conditions}

NICU also caters to patients with myasthenia gravis (MG), Guillain-Barre syndrome (GBS), status epilepticus (SE)/refractory SE, and neuroinfections. Normally these patients have a prolonged ICU course with frequent laboratory testing, thereby resulting in iatrogenic anemia. Iron deficiency anemia and low body iron status are associated with febrile seizures. ${ }^{102,103}$ In a recent survey, most respondent physicians did not feel the need for separate transfusion strategies in these patient populations as compared to general critically ill patients. ${ }^{35}$

\section{Standard Practice Points Based on Available Evidence and Guidelines}

- Minimize phlebotomies for diagnostic laboratory testing.

- In general, restrictive transfusion practices can be recommended, except in SAH and stroke patients with high chances of cerebral ischemia. However, due consideration should be given to the clinical status, associated comorbidities, and physiologic triggers.

- In hemodynamically stable patients, administer a single unit at a time and reassess the need before ordering the second unit.

- In pediatric patients, weight-based volumes should be infused $(10-15 \mathrm{~mL} / \mathrm{kg})$.

- Use leukoreduced RBC or leuco-filters for RBCT.

\section{Conclusion}

Though RBCT is extremely common in the NICU, the available evidence is poor and insufficient to guide RBCT practices. Stringent restrictive strategies may not be suitable in this population, especially in aSAH and stroke patients in whom higher $\mathrm{Hb}$ concentration $(>9 \mathrm{~g} / \mathrm{dL}$ ) seems to be associated with favorable outcome. However, in patients with other causes of ABI, blood transfusion may be considered between $\mathrm{Hb}$ concentration of 7 to $10 \mathrm{~g} / \mathrm{dL}$ giving due consideration to the underlying clinical condition. Also, transfusion practices based on cerebral oxygenation parameters seem to have a potential to individualize the transfusion therapy and remain an important avenue of future research. Thus, further randomized studies comparing the different nadir $\mathrm{Hb}$ concentrations together with the systemic and cerebral physiological triggers will immensely help in understanding and optimizing the transfusion practices in the NICU.

\section{Conflict of Interest}

None declared.

\section{References}

1 Hébert PC, Wells G, Blajchman MA, et al. A multicenter, randomized, controlled clinical trial of transfusion requirements in critical care. Transfusion Requirements in Critical Care Investigators, Canadian Critical Care Trials Group. N Engl J Med 1999;340(6):409-417

2 Lacroix J, Hébert PC, Hutchison JS, et al; TRIPICU Investigators; Canadian Critical Care Trials Group; Pediatric Acute Lung Injury and Sepsis Investigators Network. Transfusion strategies for patients in pediatric intensive care units. N Engl J Med 2007;356(16):1609-1619

3 Holst LB, Haase N, Wetterslev J, et al; TRISS Trial Group; Scandinavian Critical Care Trials Group. Lower versus higher hemoglobin threshold for transfusion in septic shock. N Engl J Med 2014;371(15):1381-1391

4 Carson JL, Stanworth SJ, Roubinian N, et al. Transfusion thresholds and other strategies for guiding allogeneic red blood cell transfusion. Cochrane Database Syst Rev 2016;10:CD002042

5 Carson JL, Guyatt G, Heddle NM, et al. Clinical practice guidelines from the AABB: red blood cell transfusion thresholds and storage. JAMA 2016;316(19):2025-2035

6 Allport LE, Parsons MW, Butcher KS, et al. Elevated hematocrit is associated with reduced reperfusion and tissue survival in acute stroke. Neurology 2005;65(9):1382-1387

7 Kimberly WT, Wu O, Arsava EM, et al. Lower hemoglobin correlates with larger stroke volumes in acute ischemic stroke. Cerebrovasc Dis Extra 2011;1(1):44-53

8 Kramer AH, Zygun DA, Bleck TP, Dumont AS, Kassell NF, Nathan B. Relationship between hemoglobin concentrations and outcomes across subgroups of patients with aneurysmal subarachnoid hemorrhage. Neurocrit Care 2009;10(2):157-165

9 Sekhon MS, McLean N, Henderson WR, Chittock DR, Griesdale DE. Association of hemoglobin concentration and mortality in critically ill patients with severe traumatic brain injury. Crit Care 2012;16(4):R128

10 Yang CJ, Hsiao KY, Su IC, Chen IC. The association between anemia and the mortality of severe traumatic brain injury in emergency department. J Trauma 2011;71(6):E132-E135

11 Litofsky NS, Martin S, Diaz J, et al. The negative impact of anemia in outcome from traumatic brain injury. World Neurosurg 2016;90:82-90

12 Kramer AH, Gurka MJ, Nathan B, Dumont AS, Kassell NF, Bleck TP. Complications associated with anemia and blood transfusion in patients with aneurysmal subarachnoid hemorrhage. Crit Care Med 2008;36(7):2070-2075

13 English SW, Chassé M, Turgeon AF, et al; Canadian Critical Care Trials Group. Anemia prevalence and incidence and red blood cell transfusion practices in aneurysmal subarachnoid hemorrhage: results of a multicenter cohort study. Crit Care 2018;22(1):169

14 Boutin A, Moore L, Lauzier F, et al. Transfusion of red blood cells in patients with traumatic brain injuries admitted to Canadian trauma health centres: a multicentre cohort study. BMJ Open 2017;7(3):e014472

15 Hemoglobin concentrations for the diagnosis of anemia and assessment of severity. vitamin and mineral nutrition information system. Geneva, Switzerland: World Health Organization; 2011 (WHO/NMH/NHD/MNM/11.1). Available at: http://apps.who.int/iris/bitstream/10665/85839/3/WHO_ NMH_NHD_MNM_11.1_eng.pdf?ua=1. Accessed December 25, 2018

16 Lelubre C, Bouzat P, Crippa IA, Taccone FS. Anemia management after acute brain injury. Crit Care 2016;20(1):152 
17 Gupta G, Wadhwa C, Garg R, Dhaiya RS, Kaushal RK. Impact of coagulation profile on outcome of head injury. J Clin Diagn Res 2016;10(1):PC04-PC06

18 Sahuquillo J, Munar F, Baguena M, Poca MA, Pedraza S, Rodríguez-Baeza A. Evaluation of cerebrovascular $\mathrm{CO}_{2}$-reactivity and autoregulation in patients with post-traumatic diffuse brain swelling (diffuse injury III). Acta Neurochir Suppl (Wien) 1998;71:233-236

19 Sahoo S, Sheshadri V, Sriganesh K, Madhsudana Reddy KR, Radhakrishnan M, Umamaheswara Rao GS. Effect of hyperoxia on cerebral blood flow velocity and regional oxygen saturation in patients operated on for severe traumatic brain injury - the influence of cerebral blood flow autoregulation. World Neurosurg 2017;98:211-216

20 Taccone FS, Citerio G; Participants in the International Multi-disciplinary Consensus Conference on Multimodality Monitoring. Advanced monitoring of systemic hemodynamics in critically ill patients with acute brain injury. Neurocrit Care 2014;21(Suppl 2):S38-S63

21 Madjdpour C, Spahn DR. Allogeneic red blood cell transfusions: efficacy, risks, alternatives and indications. $\mathrm{Br} \mathrm{J}$ Anaesth 2005;95(1):33-42

22 Chau JK, Harris JR, Seikaly HR. Transfusion as a predictor of recurrence and survival in head and neck cancer surgery patients. J Otolaryngol Head Neck Surg 2010;39(5):516-522

23 Leal-Noval SR, Rincón-Ferrari MD, Marin-Niebla A, et al. Transfusion of erythrocyte concentrates produces a variable increment on cerebral oxygenation in patients with severe traumatic brain injury: a preliminary study. Intensive Care Med 2006;32(11):1733-1740

24 Zygun DA, Nortje J, Hutchinson PJ, Timofeev I, Menon DK, Gupta AK. The effect of red blood cell transfusion on cerebral oxygenation and metabolism after severe traumatic brain injury. Crit Care Med 2009;37(3):1074-1078

25 Surve RM, Muthuchellappan R, Rao GS, Philip M. The effect of blood transfusion on central venous oxygen saturation in critically ill patients admitted to a neurointensive care unit. Transfus Med 2016;26(5):343-348

26 Muthuchellappan R, Shaikh NA, Surve RM, Ganne URS, Philip $M$. Regional cerebral tissue oxygen saturation changes following blood transfusion in neuro-intensive care unit patients-a pilot observational study. Transfus Med 2018;28:304-309

27 Leal-Noval SR, Arellano-Orden V, Muñoz-Gómez M, et al. Red blood cell transfusion guided by near infrared spectroscopy in neurocritically ill patients with moderate or severe anemia: a randomized, controlled trial. J Neurotrauma 2017;34(17):2553-2559

28 Napolitano LM, Kurek S, Luchette FA, et al; EAST Practice Management Workgroup; American College of Critical Care Medicine (ACCM) Taskforce of the Society of Critical Care Medicine (SCCM). Clinical practice guideline: red blood cell transfusion in adult trauma and critical care. J Trauma 2009;67(6):1439-1442

29 Patient blood management guidelines. Lyneham, ACT: National Blood Authority Australia; 2012. Available at: http://www. blood. gov.au/pbm-guidelines. Accessed November 14, 2018

30 Retter A, Wyncoll D, Pearse R, et al; British Committee for Standards in Haematology. Guidelines on the management of anaemia and red cell transfusion in adult critically ill patients. Br J Haematol 2013;160(4):445-464

31 Klein AA, Arnold P, Bingham RM, et al. Association of Anaesthetists of Great Britain and Ireland. AAGBI guidelines: the use of blood components and their alternatives. Anaesthesia 2016;71:829-842

32 Tasker RC, Turgeon AF, Spinella PC; Pediatric Critical Care Transfusion and Anemia Expertise Initiative (TAXI); Pediatric Critical Care Blood Research Network (BloodNet), and the
Pediatric Acute Lung Injury and Sepsis Investigators (PALISI) Network. Recommendations on RBC transfusion in critically ill children with acute brain injury from paediatric critical care transfusion and anaemia expertise initiative. Pediatr Crit Care Med 2018;19(9S, Suppl 1):S133-S136

33 Huijben JA, Volovici V, Cnossen MC, et al; CENTER-TBI investigators and participants. Variation in general supportive and preventive intensive care management of traumatic brain injury: a survey in 66 neurotrauma centers participating in the Collaborative European NeuroTrauma Effectiveness Research in Traumatic Brain Injury (CENTER-TBI) study. Crit Care 2018;22(1):90

34 Badenes R, Oddo M, Suarez JI, et al. Hemoglobin concentrations and RBC transfusion thresholds in patients with acute brain injury: an international survey. Crit Care 2017;21(1):159

35 Bouma GJ, Muizelaar JP, Stringer WA, Choi SC, Fatouros $\mathrm{P}$, Young HF. Ultra-early evaluation of regional cerebral blood flow in severely head-injured patients using xenonenhanced computerized tomography. J Neurosurg 1992; 77(3):360-368

36 Lee JH, Kelly DF, Oertel M, et al. Carbon dioxide reactivity, pressure autoregulation, and metabolic suppression reactivity after head injury: a transcranial Doppler study. J Neurosurg 2001;95(2):222-232

37 Steyerberg EW, Mushkudiani N, Perel P, et al. Predicting outcome after traumatic brain injury: development and international validation of prognostic scores based on admission characteristics. PLoS Med 2008;5(8):e165, discussion e165

38 Van Beek JG, Mushkudiani NA, Steyerberg EW, et al. Prognostic value of admission laboratory parameters in traumatic brain injury: results from the IMPACT study. J Neurotrauma 2007;24(2):315-328

39 Griesdale DE, Sekhon MS, Menon DK, et al. Hemoglobin area and time index above $90 \mathrm{~g} / \mathrm{L}$ are associated with improved 6-month functional outcomes in patients with severe traumatic brain injury. Neurocrit Care 2015;23(1):78-84

40 Salim A, Hadjizacharia P, DuBose J, et al. Role of anemia in traumatic brain injury. J Am Coll Surg 2008;207(3):398-406

41 Al-Dorzi HM, Al-Humaid W, Tamim HM, et al. Anemia and blood transfusion in patients with isolated traumatic brain injury. Crit Care Res Pract 2015;2015:1-7

42 Elterman J, Brasel K, Brown S, et al; Resuscitation Outcomes Consortium Investigators. Transfusion of red blood cells in patients with a prehospital Glasgow coma scale score of 8 or less and no evidence of shock is associated with worse outcomes. J Trauma Acute Care Surg 2013;75(1):8-14, discussion 14

43 East JM, Viau-Lapointe J, McCredie VA. Transfusion practices in traumatic brain injury. Curr Opin Anaesthesiol 2018;31(2):219-226

44 George ME, Skarda DE, Watts CR, Pham HD, Beilman GJ. Aggressive red blood cell transfusion: no association with improved outcomes for victims of isolated traumatic brain injury. Neurocrit Care 2008;8(3):337-343

45 Robertson CS, Hannay HJ, Yamal JM, et al; Epo Severe TBI Trial Investigators. Effect of erythropoietin and transfusion threshold on neurological recovery after traumatic brain injury: a randomized clinical trial. JAMA 2014;312(1):36-47

46 Warner MA, O'Keeffe T, Bhavsar P, et al. Transfusions and longterm functional outcomes in traumatic brain injury. J Neurosurg 2010;113(3):539-546

47 Leal-Noval SR, Muñoz-Serrano Á, Arellano-Orden V, et al. Effects of red blood cell transfusion on long-term disability of patients with traumatic brain injury. Neurocrit Care 2016;24(3):371-380

48 McCredie VA, Piva S, Santos M, et al. The impact of red blood cell transfusion on cerebral tissue oxygen saturation in severe traumatic brain injury. Neurocrit Care 2017;26(2):247-255 
49 Oddo M, Levine JM, Kumar M, et al. Anemia and brain oxygen after severe traumatic brain injury. Intensive Care Med 2012;38(9):1497-1504

50 Yamal JM, Rubin ML, Benoit JS, et al. Effect of hemoglobin transfusion threshold on cerebral hemodynamics and oxygenation. J Neurotrauma 2015;32(16):1239-1245

51 Sekhon MS, Griesdale DE, Czosnyka M, et al. The effect of red blood cell transfusion on cerebral autoregulation in patients with severe traumatic brain injury. Neurocrit Care 2015;23(2):210-216

52 Timofeev I, Carpenter KL, Nortje J, et al. Cerebral extracellular chemistry and outcome following traumatic brain injury: a microdialysis study of 223 patients. Brain 2011;134(Pt 2): 484-494

53 Hutchinson PJ, Jalloh I, Helmy A, et al. Consensus statement from the 2014 International Microdialysis Forum. Intensive Care Med 2015;41(9):1517-1528

54 Bell DL, Kimberly WT, Yoo AJ, et al. Low neurologic intensive care unit hemoglobin as a predictor for intra-arterial vasospasm therapy and poor discharge modified Rankin scale in aneurysmal subarachnoid haemorrhage-induced cerebral vasospasm. J Neurointerv Surg 2015;7(6):438-442

55 Ayling OGS, Ibrahim GM, Alotaibi NM, Gooderham PA, Macdonald RL. Anemia after aneurysmal subarachnoid hemorrhage is associated with poor outcome and death. Stroke 2018;49(8):1859-1865

56 Stein M, Brokmeier L, Herrmann J, et al. Mean hemoglobin concentration after acute subarachnoid hemorrhage and the relation to outcome, mortality, vasospasm, and brain infarction. J Clin Neurosci 2015;22(3):530-534

57 Smith MJ, Le Roux PD, Elliott JP, Winn HR. Blood transfusion and increased risk for vasospasm and poor outcome after subarachnoid hemorrhage. J Neurosurg 2004;101(1):1-7

58 Kumar MA, Boland TA, Baiou M, et al. Red blood cell transfusion increases the risk of thrombotic events in patients with subarachnoid hemorrhage. Neurocrit Care 2014;20(1):84-90

59 Festic E, Rabinstein AA, Freeman WD, et al. Blood transfusion is an important predictor of hospital mortality among patients with aneurysmal subarachnoid hemorrhage. Neurocrit Care 2013;18(2):209-215

60 Kumar MA, Levine J, Faerber J, et al. The effects of red blood cell transfusion on functional outcome after aneurysmal subarachnoid hemorrhage. World Neurosurg 2017;108:807-816

61 Oddo M, Milby A, Chen I, et al. Hemoglobin concentration and cerebral metabolism in patients with aneurysmal subarachnoid hemorrhage. Stroke 2009;40(4):1275-1281

62 Kurtz P, Schmidt JM, Claassen J, et al. Anemia is associated with metabolic distress and brain tissue hypoxia after subarachnoid hemorrhage. Neurocrit Care 2010;13(1):10-16

63 Kurtz P, Helbok R, Claassen J, et al. The effect of packed red blood cell transfusion on cerebral oxygenation and metabolism after subarachnoid hemorrhage. Neurocrit Care 2016;24(1):118-121

64 Dhar R, Zazulia AR, Videen TO, Zipfel GJ, Derdeyn CP, Diringer MN. Red blood cell transfusion increases cerebral oxygen delivery in anemic patients with subarachnoid hemorrhage. Stroke 2009;40(9):3039-3044

65 Dhar R, Zazulia AR, Derdeyn CP, Diringer MN. RBC transfusion improves cerebral oxygen delivery in subarachnoid hemorrhage. Crit Care Med 2017;45(4):653-659

66 Naidech AM, Bendok BR, Ault ML, Bleck TP. Monitoring with the Somanetics INVOS $5100 C$ after aneurysmal subarachnoid hemorrhage. Neurocrit Care 2008;9(3):326-331

67 Diringer MN, Bleck TP, Claude Hemphill J III, et al; Neurocritical Care Society. Critical care management of patients following aneurysmal subarachnoid hemorrhage: recommendations from the Neurocritical Care Society's Multidisciplinary Consensus Conference. Neurocrit Care 2011;15 (2):211-240
68 Tanne D, Molshatzki N, Merzeliak O, Tsabari R, Toashi M, Schwammenthal Y. Anemia status, hemoglobin concentration and outcome after acute stroke: a cohort study. BMC Neurol 2010;10:22

69 Kellert L, Herweh C, Sykora M, et al. Loss of penumbra by impaired oxygen supply? Decreasing hemoglobin levels predict infarct growth after acute ischemic stroke: Stroke: Relevant Impact of Hemoglobin, Hematocrit and Transfusion (STRAIGHT)-an observational study. Cerebrovasc Dis Extra 2012;2(1):99-107

70 Barlas RS, Honney K, Loke YK, et al. Impact of hemoglobin levels and anemia on mortality in acute stroke: analysis of UK Regional Registry Data, Systematic Review, and Meta-Analysis. J Am Heart Assoc 2016;5(8):e003019

71 Bhatia RS, Garg RK, Gaur SP, et al. Predictive value of routine hematological and biochemical parameters on 30-day fatality in acute stroke. Neurol India 2004;52(2):220-223

72 Kellert L, Schrader F, Ringleb P, Steiner T, Bösel J. The impact of low hemoglobin levels and transfusion on critical care patients with severe ischemic stroke: STroke: RelevAnt Impact of HemoGlobin, Hematocrit and Transfusion (STRAIGHT)-an observational study. J Crit Care 2014;29(2):236-240

73 Sharma K, Johnson DJ, Johnson B, Frank SM, Stevens RD. Hemoglobin concentration does not impact 3-month outcome following acute ischemic stroke. BMC Neurol 2018;18(1):78

74 Ke Z, Zhao Y, Wang C, Cai Z. The alliance with expanding blood volume and correcting anemia is an effective therapeutic measure for the adult anemia patients of acute cerebral infarction. Int J Neurosci 2018;128(5):429-434

75 Dexter F, Hindman BJ. Effect of haemoglobin concentration on brain oxygenation in focal stroke: a mathematical modelling study. Br J Anaesth 1997;79(3):346-351

76 Kumar MA, Rost NS, Snider RW, et al. Anemia and hematoma volume in acute intracerebral hemorrhage. Crit Care Med 2009;37(4):1442-1447

77 Sheth KN, Gilson AJ, Chang Y, et al. Packed red blood cell transfusion and decreased mortality in intracerebral hemorrhage. Neurosurgery 2011;68(5):1286-1292

78 Petrikov SS, Titova IuV, Solodov AA, Guseĭnova KhT, Krylov VV. Effect of hemotransfusion on brain oxygenation and metabolism in patients with intracranial hemorrhages [in Russian]. Anesteziol Reanimatol 2009;5(5):32-35

79 Javed I, Sultan T, Rehman ZU, Yaseen MR. Clinical spectrum and outcome of cerebral venous sinus thrombosis in children. J Coll Physicians Surg Pak 2018;28(5):390-393

80 Liu K, Song B, Gao Y, et al. Long-term outcomes in patients with anemia and cerebral venous thrombosis. Neurocrit Care 2018;29(3):463-468

81 Alan N, Seicean A, Seicean S, Neuhauser D, Weil RJ. Impact of preoperative anemia on outcomes in patients undergoing elective cranial surgery. J Neurosurg 2014;120(3):764-772

82 Ali Z, Hassan N, Mehdi S, Shah MA, Bijli AH, Khan T. A review of the blood transfusion practices in neuroanesthesia in the perioperative period in a tertiary care hospital. Int J Res Med Sci 2017;5(5):1858-1861

83 Vassal O, Desgranges FP, Tosetti S, et al. Risk factors for intraoperative allogeneic blood transfusion during craniotomy for brain tumor removal in children. Paediatr Anaesth 2016;26(2):199-206

84 Kisilevsky A, Gelb AW, Bustillo M, Flexman AM. Anaemia and red blood cell transfusion in intracranial neurosurgery: a comprehensive review. Br J Anaesth 2018;120(5):988-998

85 Le Roux PD, Elliott JP, Winn HR. Blood transfusion during aneurysm surgery. Neurosurgery 2001;49(5):1068-1074, discussion 1074-1075

86 Bhatnagar S, Udaya IB, Umamaheswara Rao GS. An audit of blood transfusion In elective neuro-surgery. Indian J Anaesth 2007;51(3):200-204 
87 Cha CW, Deible C, Muzzonigro T, Lopez-Plaza I, Vogt M, Kang JD. Allogeneic transfusion requirements after autologous donations in posterior lumbar surgeries. Spine 2002;27(1):99-104

88 Brecknell JE, McLean CA, Hirano H, Malham GM. Disseminated intravascular coagulation complicating resection of a malignant meningioma. Br J Neurosurg 2006;20(4):239-241

89 Eom KS, Kim JM, Kim TY. Disseminated intravascular coagulation in a patient undergoing removal of metastatic brain tumor. J Korean Neurosurg Soc 2008;44(5):341-344

90 Atzil S, Arad M, Glasner A, et al. Blood transfusion promotes cancer progression: a critical role for aged erythrocytes. Anesthesiology 2008;109(6):989-997

91 Kudo H, Fujita H, Hanada Y, Hayami H, Kondoh T, Kohmura E. Cytological and bacteriological studies of intraoperative autologous blood in neurosurgery. Surg Neurol 2004;62(3):195199, discussion 199-200

92 Patil H, Garg N, Navakar D, Banabokade L. Clinical experience of autologous blood transfusion in neurosurgery: prospective study in central India. World Neurosurg 2018;115:e539-e543

93 Awada WN, Mohmoued MF, Radwan TM, Hussien GZ, Elkady HW. Continuous and noninvasive hemoglobin monitoring reduces red blood cell transfusion during neurosurgery: a prospective cohort study. J Clin Monit Comput 2015;29(6):733-740

94 Oppitz PP, Stefani MA. Acute normovolemic hemodilution is safe in neurosurgery. World Neurosurg 2013;79(5-6):719-724

95 McGirr A, Pavenski K, Sharma B, Cusimano MD. Blood conservation in neurosurgery: erythropoietin and autologous donation. Can J Neurol Sci 2014;41(5):583-589
96 Hooda B, Chouhan RS, Rath GP, Bithal PK, Suri A, Lamsal R. Effect of tranexamic acid on intraoperative blood loss and transfusion requirements in patients undergoing excision of intracranial meningioma. J Clin Neurosci 2017;41:132-138

97 Hirsch GH, Menard MR, Anton HA. Anemia after traumatic spinal cord injury. Arch Phys Med Rehabil 1991;72(3):195-201

98 Frisbie JH. Anemia and hypoalbuminemia of chronic spinal cord injury: prevalence and prognostic significance. Spinal Cord 2010;48(7):566-569

99 Purvis TE, Goodwin CR, De la Garza-Ramos R, et al. Effect of liberal blood transfusion on clinical outcomes and cost in spine surgery patients. Spine J 2017;17(9):1255-1263

100 Epstein NE. Perioperative visual loss following prone spinal surgery: a review. Surg Neurol Int 2016;7(Suppl 13): S347-S360

101 Neunhoeffer F, Hofbeck M, Schuhmann MU, et al. Cerebral oxygen metabolism before and after RBC transfusion in infants following major surgical procedures. Pediatr Crit Care Med 2018;19(4):318-327

102 Mann SA, Williams LA III, Marques MB, Pham HP. Hospitalacquired anemia due to diagnostic and therapy-related blood loss in inpatients with myasthenia gravis receiving therapeutic plasma exchange. J Clin Apher 2018;33(1):14-20

103 Zareifar S, Hosseinzadeh HR, Cohan N. Association between iron status and febrile seizures in children. Seizure 2012;21(8):603-605 